BOŻENA SKIBIŃSKA

Stowarzyszenie Rodzin Katolickich

w Gorzowie Wielkopolskim

\title{
„SKAZANI NA SAMOTNOŚĆ?" \\ O KONSEKWENCJACH IZOLACJI SPOŁECZNEJ W WYBRANYCH JEJ KONTEKSTACH
}

\begin{abstract}
Skibińska Bożena, „Skazani na samotność?” O konsekwencjach izolacji społecznej w wybranych jej kontekstach ["Doomed to Loneliness?" On the Consequences of Social Isolation in Selected Contexts]. Studia Edukacyjne nr 44, 2017, Poznań 2017, pp. 265-284. Adam Mickiewicz University Press. ISSN 1233-6688. DOI: $10.14746 /$ se.2017.44.16
\end{abstract}

Today, disturbingly often, it is possible to witnesses the effects of stigma and exclusion not only of the individual, but of whole groups of people, the result of reinforced, persistent stereotypes and prejudices about the subjects mentioned. They cause wrong social attitudes, expressed by the deprivation of the isolated persons of their rights to create and nurture relationships based on closeness and love, and often doom these people to a life of total seclusion. This article is an attempt to show the far-reaching consequences of depriving persons with intellectual disabilities and denying the right of self-expression. It is also a critical reflection on the irregularities experienced by people, towards whom it is introduced, in terms of institutional isolation. At the same time, by presenting the results of personal research and conclusions, attention is being drawn to the fact that in our society there is an emerging hope for positive changes in the daily treatment of the socially isolated individuals. Yet, there is a constant need for a continuous reinforcement of the public awareness of the fact that the reintegration of these excluded individuals in the community benefits both the parties involved.

Taking up the theme of stigma and social exclusion of persons with intellectual disabilities and convicts is considered important and relevant, as this is an issue which remains topical and gives rise to multiple moral dilemmas.

Key words: loneliness, social isolation, stigma, deprivation, intellectual disability, incarcerated

\section{Wprowadzenie}

Każdy człowiek w ciągu całego życia i we wciąż poszerzającym się środowisku społecznym nieustannie nawiązuje wiele różnorakich więzi. Pomiędzy nim a innymi jednostkami ludzkimi zawiązują się wszechstronne, bardziej lub mniej trwałe relacje i powiązania decydujące o jego miejscu $\mathrm{w}$ tym śro- 
dowisku i uświadomionej lub nieuświadomionej roli, jaką dobrowolnie bądź pod przymusem przychodzi mu w nim pełnić. Poprzez stosunek do otaczających jednostkę ludzi i świata oraz wszelkie zachodzące między nimi interakcje określa się osobowość człowieka, której nie można całkowicie oddzielić od pełnionych przez niego ról. Zatem, ludzka osobowość nie jest w stanie prawidłowo funkcjonować bez świata ludzi i rzeczy, będącego dla każdego punktem odniesienia i miejscem, którego immanentną częścią staje się już w chwili narodzin. Pozostawanie $\mathrm{w}$ określonej relacji ze światem zewnętrznym jest warunkiem koniecznym i regulującym sprawne funkcjonowanie osobowości ludzkiej. Dobre samopoczucie, możliwość samorealizacji i nawiązywania głębokich więzi emocjonalnych, wewnętrzna akceptacja oraz autonomiczne i czynne uczestnictwo w świecie ludzi i rzeczy, tworzą każdemu człowiekowi optymalne warunki funkcjonowania społecznego i osobistego, umożliwiając tym samym osiągnięcie zarówno zewnętrznej, jak i wewnętrznej harmonii. Niekiedy jednak układ otaczających człowieka warunków może powodować zachwianie równowagi psychicznej jednostki i zaburzenia całokształtu relacji pomiędzy nią a otoczeniem. Do takich sytuacji należy zaliczyć przede wszystkim warunki, w których wzajemne oddziaływanie człowieka oraz świata rzeczy i ludzi stają się w znacznym stopniu utrudnione bądź ograniczone. Zerwanie, czy choćby zawieszenie istniejącej relacji człowiek - świat, nazywane jest izolacją ${ }^{1}$.

Prawidłowe funkcjonowanie i względnie dobre samopoczucie człowieka zależy w przeważającej mierze od stopnia zaspokojenia podstawowych potrzeb. Niektóre z nich, jak potrzeba jedzenia czy oddychania, stanowiąc warunek konieczny do rozwoju biologicznego oraz zachowania życia, nazywane są potrzebami gatunkowymi lub pierwotnymi, a ich zaspokojenie odbywa się poprzez dostarczenie organizmowi pewnych „wartości” z zewnątrz, co niewątpliwie świadczy o zależności ludzkiego organizmu od świata. Inne wykształcają się w ciągu życia i są efektem indywidualnego uczenia się poprzez fizyczne, a także psychologiczne interakcje człowieka ze środowiskiem. Te noszą miano potrzeb psychicznych. Do najważniejszych należy zaliczyć potrzeby: akceptacji, bezpieczeństwa, kontaktu emocjonalnego i miłości. Wszystkie ludzkie potrzeby, bez względu na to, czy wchodzą w skład struktury biologicznej czy osobowościowej, mają tę swoistą cechę, że „lubią być zaspokojone". Każda sytuacja, w której na drodze do zaspokojenia jakiejkolwiek potrzeby pojawiają się komplikacje lub w żaden sposób nie dające się pokonać przeszkody, nazywana jest deprywacją². Sytuację, w której wystę-

\footnotetext{
${ }^{1}$ B. Waligóra, Funkcjonowanie człowieka w warunkach izolacji więziennej, Poznań 1974.

2 B. Waligóra, Deprywacja potrzeb u osób pozbawionych wolności, [w:] Problemy wspótczesnej penitencjarystyki w Polsce, red. B. Hołyst, Warszawa 1984.
} 
powanie jakichś czynników może stanowić źródło zagrożenia dla zdrowia lub życia człowieka, bądź uniemożliwiać czy zakłócać zaspokojenie potrzeb lub powodować pozbawienie kogoś najwyżej cenionych przez niego wartości, nazywa się także sytuacją trudną ${ }^{3}$. Bez względu na to, co jest powodem „odseparowania” człowieka od świata ludzi i rzeczy, zwłaszcza zaś dokonanego w sposób nagły i radykalny, nie ma wątpliwości, że wiele zaspokojonych dotąd przez niego potrzeb zaczyna ulegać natychmiastowej deprywacji i frustracji. Co więcej, należy stanowczo zaznaczyć, iż każda forma izolacji pozbawia człowieka czegoś lub redukuje możliwość korzystania z dostępnych w warunkach „wolnościowych” przywilejów. Biorąc pod uwagę, że równocześnie osoba izolowana doświadcza szeregu często niczym nieuzasadnionych "ataków”, nacisków i kontroli, nie powinno dziwić, że odczuwa ona wyjątkowo bolesną utratę osobistej i społecznej godności. Owa strata jest dotkliwie odczuwana nawet przez najsilniejsze i najodporniejsze psychicznie jednostki, których funkcjonowanie w sytuacji izolacji, nierzadko wywołane lękiem, przerażeniem i dezorganizacją, przepełnione jest irracjonalizmem i impulsywnościąa

\section{O deprywacji potrzeb i ujemnych konsekwencjach izolacji}

Opisanie skutków izolacji i dokonującej się „w niej” nieustannie deprywacji najważniejszych ludzkich potrzeb sprawia wciąż niemałą trudność, gdyż nie do końca zostały one poznane. Wiadomo jednak, że każdy człowiek doświadczający odosobnienia, osamotnienia, czy braku głębokich relacji z ludźmi pozbawiony jest możliwości „bycia sobą”, co prowadzi do utraty energii i radości życia. Osoby te stale za czymś tęsknią, wciąż czegoś im brakuje, każda z nich ma subiektywne i ukryte pragnienia, a świadomość braku możliwości pełnej ich realizacji powoduje ich stopniową "śmierć” emocjonalną ${ }^{5}$.

W zależności od rodzaju izolacji, czasu jej trwania i cech osobowości osoby jej poddanej, prowadzi ona do szeregu konsekwencji związanych z frustracją i deprywacją najistotniejszych ludzkich potrzeb. Do najpoważniejszych należy zaliczyć zaburzenia w sferze przeżyć psychicznych, doznań zmysłowych i postaw wobec otaczającego świata.

\footnotetext{
${ }^{3}$ M. Adamczyk, Choroba i jej indywidualna koncepcja, [w:] Elementy psychologii klinicznej, red. B Waligóra, Poznań 1985.

${ }^{4}$ B. Waligóra, Funkcjonowanie człowieka.

${ }^{5} \mathrm{~T}$. Zbyrad, Instytucje opieki totalnej jako forma zniewolenia i kontroli nad człowiekiem potrzebującym pomocy - na przykładzie domów pomocy społecznej, Roczniki Nauk Społecznych, 2012, $\operatorname{IV}(40), 2$.
} 
Utrzymujący się stan deprywacji jest przyczyną pojawiania się negatywnych emocji powodujących brak możliwości normalnego funkcjonowania i rozwoju osobowości. Co więcej, jeśli stan ten ulega przedłużeniu, może dojść nawet do całkowitego jej rozpadu. Ograniczenie szans na zaspokojenie potrzeb własnymi siłami jest także powodem zupełnego wygaśnięcia motywacji osób izolowanych, ich bierności i zniechęcenia, a także zachowań agresywnych i autoagresywnych, buntu wobec norm, czy stałego przygnębienia. Deprywacja potrzeb często powoduje także znaczne nasilenie się odczuwania tych pragnień, których zaspokojenie jest w najwyższym stopniu utrudnione bądź paradoksalnie unikanie przedmiotu umożliwiającego zaspokojenie potrzeby w sytuacji, kiedy oczekiwanie na zaspokojenie trwa zbyt długo ${ }^{6}$. Osoby poddawane długotrwałej izolacji charakteryzują się dużymi zmianami w sferze emocjonalnej, przejawiającymi się licznymi i poważnymi zaburzeniami o charakterze nerwicowym, takimi jak: unikanie kontaktów z innymi ludźmi, niepewność i nieufność oraz przesadna ostrożność w relacjach z nimi, brak poczucia sensu oraz umiejętności panowania nad nastrojami i labilność emocjonalna spowodowana niską samooceną, złe samopoczucie, depresja, apatia, skrajny introwertyzm, zachowania psychotyczne i neurotyczne prowadzące do pojawiania się patologicznego lęku, nieumiejętność właściwej oceny rzeczywistości, zaburzenia instynktu samozachowawczego będące przyczyną podejmowania prób samobójczych oraz zaburzenia życia uczuciowego przejawiające się lękiem seksualnym i wiele innych zaburzeń wynikających z nieustannej deprywacji, a prowadzących do trwałego poczucia zagrożenia oraz upośledzenia i zubożenia przebiegu wszelkich procesów intelektualnych ${ }^{7}$. Nie pozostaje to bez znaczenia dla jakości życia osób izolowanych społecznie.

Mówiąc o jakości życia, czyli określonym sposobie życia i towarzyszących mu odczuciach, należy wziąć pod uwagę rodzaje przeżyć człowieka, zaangażowanie, uczuciowe nastroje oraz charakter relacji zarówno z samym sobą, jak i z innymi ludźmi. Ważne są także wszelkie realizowane przez człowieka działania i ich efekty oraz dynamika i kierunek osobistego rozwoju. Wyróżniamy cztery podstawowe formy życia psychicznego: przeżywanie, z którym ściśle wiąże się wartościowanie zdarzeń, ocena własnego życia, wizja samego siebie i świata oraz umiejętność dokonywania życiowych wyborów; pozostawanie $\mathrm{w}$ egzystencjalnej symbiozie $\mathrm{z}$ innymi ludźmi i światem, łączące się z potrzebą przynależności do jakiejś wspólnoty, potrzebą tworzenia więzi, samoakceptacji i samopoznania; działanie, które jest głównym narzędziem mającym służyć człowiekowi w celu adaptacji do świata oraz rozwój twórczy,

${ }^{6}$ D. Sarzała, Patologiczne zachowania więźniów w kontekście izolacji i resocjalizacji penitencjarnej, Warszawa 2013.

${ }^{7}$ Tamże. 
który winien być ukierunkowany na przeżywanie, a także refleksję dotyczącą osobistych doświadczeń. Wszystkie formy życia psychicznego odnoszą się do wymiarów życia psychicznego, przekładających się na sfery jakości życiå.

W sferze psychofizycznej zawiera się ludzka seksualność - nieodłączny element ludzkiej osobowości. Seksualność najsilniej związana jest z potrzebą bliskości i miłości. Możliwość realizowania się w nich nadaje ludzkiemu życiu sens i znaczenie. Sfera psychofizyczna to popędowość i cielesność, które mogą być w istotny sposób zaburzone, na przykład w wyniku choroby. Samoakceptacja i poczucie własnej wartości oraz przynależności i bezpieczeństwa, a także społecznej tożsamości mogą być silnie „zniekształcone” w wyniku poczucia samotności. Ma to ogromny wpływ na psychospołeczną sferę życia. Umiejętność życia w zgodzie z samym sobą, poczucie autentyczności oraz odpowiedzialności za siebie i swoje życie wiąże się natomiast ze sferą podmiotową, której zaburzenie może powodować głęboki brak poczucia indywidualności. Zdolność do ponoszenia odpowiedzialności za własne postępowanie, a także życie $\mathrm{w}$ zgodzie $\mathrm{z}$ własnym sumieniem wiąże się ze sferą metafizyczną. Brak poczucia sensu z pewnością nie sprzyja zachowaniu równowagi w metafizycznej sferze jakości życia ${ }^{9}$. Należy stanowczo zaznaczyć, że u osób poddanych społecznej izolacji, zwłaszcza zaś u jednostek, które dotyka wyraźne napiętnowanie, wszystkie wymienione sfery ulegają silnemu "zdeformowaniu".

\section{Społeczne piętno: czyli o "drodze do zniewolenia"}

Skoro mowa o napiętnowaniu, warto przez chwilę „pochylić się" nad samym pojęciem „piętna”, czy zamiennie stosowanym, lecz posiadającym równie pejoratywny wydźwięk pojęciem „stygmatu”, ich pochodzeniu, mniej lub bardziej świadomym „stosunkiem” "ogółu” do osób „dotkniętych” „naznaczeniem” oraz „relacji” pomiędzy nimi.

Psychologia społeczna definiuje "piętno" jako „sytuację jednostki pozbawionej pełnej społecznej akceptacji"10. Termin został utworzony już przez starożytnych Greków, jako określenie wypalanych bądź wycinanych na ludzkim ciele znaków świadczących o moralnym statusie ich "nosiciela”, któremu przypisywano nadzwyczajne i jednocześnie złe cechy. "Nosiciel” stygmatu utożsamiany był ze wszystkim, co w ludzkiej percepcji jawi sięjako odmienne,

${ }^{8}$ A. Nomejko, G. Dolińska-Zygmunt, Z. Zdrojewicz, Poczucie jakości życia a satysfakcja z życia seksualnego - badania własne, Seksuologia Polska, 2012, 10(2).

${ }^{9}$ D. Sarzała, Patologiczne zachowania więźniów.

${ }^{10}$ E. Goffman, Piętno. Rozważania o zranionej tożsamości, Gdańsk 2005, s. 27. 
ułomne, nieczyste, bezproduktywne, zdradzieckie, skażone, kryminogenne, a zatem szczególnie niepożądane, zwłaszcza w publicznej przestrzeni. Przez wieki dotknięci społecznym piętnem poddawani byli segregacji, wykluczeniu i izolacji. Ich zasadność potwierdzały również głoszone przez przedstawicieli Kościoła nauki, jakoby fizyczna skaza czy inność były immanentnie powiązane z grzechem, winą, karą i przekleństwem, a tym samym byciem niegodnym uwagi i łaski Pana. Niezależnie, jakiego rodzaju piętno "nosi” osoba nim "obdarowana” (brzydota cielesna, wady charakteru, które przypisujemy słabej woli, niepohamowanym popędom, niebezpiecznym przekonaniom, o których wnioskujemy na podstawie zaistniałych w czyimś życiu faktów, jak: niepełnosprawność, zaburzenia psychiczne, kryminalna przeszłość, czy grupowe piętno wyznania, rasy czy narodowości), we wszystkich ich odmianach znajdujemy te same socjologiczne właściwości. Kiedy osoba, która w normalnych społecznych interakcjach mogłaby być z łatwością zaakceptowana, zostaje "naznaczona” łatwo zauważalnym, odpychającym nas od niej atrybutem, to fakt „naznaczenia” powoduje jednocześnie deprecjonowanie innych jej cech i właściwości, zdolności (wartości), które mogłyby wywołać w nas pozytywne odczucia, a nawet podziw. $Z$ założenia nie traktujemy osoby napiętnowanej jako pełnowartościowego człowieka i opierając się na takim założeniu, stosujemy wobec niej najróżniejsze formy ograniczeń, dyskryminacji i ucisku, odbieramy prawo do należytego uznania i szacunku, przyczyniając się (mniej lub bardziej świadomie) do znacznego zmniejszenia jej szans na samorealizację i normalne funkcjonowanie. W rezultacie doprowadzamy do sytuacji, w której osoba napiętnowana szuka i zazwyczaj odnajduje w sobie wszystkie cechy, które niesłusznie przypisało jej społeczeństwo i kwestionuje te spośród swoich atrybutów, które dotąd uznawała za niewątpliwe. Innymi słowy, stawiając pewnego rodzaju bariery, „niewidzialne” mury, niemożliwe do pokonania przez napiętnowanych granice, powodujemy, że społeczeństwo "staje się" swoistą goffmanowską instytucją totalną, z której „naznaczeni” w żaden sposób nie mogą się wydostać. Mogą jedynie tkwić jako „pensjonariusze" i „strażnicy” w jednej osobie i niezależnie od tego, czy w zgodzie z obowiązującym "regulaminem” czy wbrew niemu zawsze w poczuciu zniewolenia i (mimo tłumu) ogromnego osamotnienia ${ }^{11}$.

\section{Socjologiczna "wizja" samotności}

Nie bez powodu użyto w tym miejscu pojęcia „osamotnienie". Istnieje bowiem zasadnicza różnica pomiędzy nim a pojęciem „samotności”. Przede

${ }^{11}$ Tamże. 
wszystkim, terminu "samotność" nie stosuje się w socjologii ${ }^{12}$, co nie pozostaje tu bez znaczenia, zważywszy, że przedmiotem niniejszych rozważań są konsekwencje izolacji społecznej osób „napiętnowanych”, a zatem konsekwencje procesów zachodzących pomiędzy grupami ludzi powiązanych siecią wzajemnych zależności. Nie oznacza to jednak, że w socjologii problem samotności nie istnieje - jest bowiem szeroko dyskutowany i krytykowany jako rezultat przemian nowoczesnego i ponowoczesnego (współczesnego) społeczeństwa, generującego samotność przybierającą postać problemów wykluczenia, dehumanizacji, dyskryminacji, czy niesprawiedliwości ${ }^{13}$.

Literatura przedmiotu podaje, iż przyczyn samotności (w ujęciu socjologicznym) należy upatrywać szczególnie w: będącym wynikiem rozwoju techniki i specjalizacji osłabieniu komunikacji, procesach urbanizacji, wzroście społecznej mobilności, negatywnym wpływie mediów, czy chociażby zmianach modelu rodziny; człowiek zaś najczęściej odczuwa osamotnienie w sytuacjach, gdy: umierają lub odchodzą od niego ludzie zapewniający mu dotąd poczucie społecznej, duchowej i towarzyskiej wspólnoty; pomimo obecności innych doświadcza wyizolowania, wynikającego z braku zrozumienia i odrzucenia z powodu "odmienności” jego wewnętrznego świata; pomimo dążenia do kochania i bycia kochanym, jego miłość, z różnych przyczyn, zostaje odrzucona; odczuwa osamotnienie w poczuciu odpowiedzialności za poczynione zło, a także kiedy staje wobec konieczności własnej śmierci ${ }^{14}$. Nie ma tu żadnej wzmianki o człowieku, ludziach, całych grupach osób izolowanych społecznie, które doświadczają niemalże permanentnego osamotnienia wcale nie $\mathrm{w}$ wyniku postępu cywilizacyjnego, szeroko rozumianych przemian społecznych, czy utraty bliskich, lecz będącego konsekwencją głębokiego sprzeciwu rzeszy ludzi wobec ich prawa do tworzenia i pielęgnowania najbardziej pożądanych przez człowieka relacji, wobec ich prawa do życia w miłości, pełnego jej przeżywania i wyrażania. W wielu przypadkach otwarte manifestowanie niczym nieuzasadnionego sprzeciwu, wynikającego głównie z niewiedzy, a także wciąż istniejących i stale powielanych na temat osób „napiętnowanych” stereotypów, jest niczym wyrok dożywotniego pozbawienia człowieka radości i szczęścia, jakie mogłaby dać mu możliwość kochania i bycia kochanym.

Owymi „napiętnowanymi skazańcami”, którym (w moim odczuciu) $\mathrm{w}$ największym stopniu prawa do realizowania się $\mathrm{w}$ tej sferze życia systematycznie się odmawia, są osoby z niepełnosprawnością intelektualną i osa-

${ }^{12}$ D. Ślęczek-Czakon, Samotność, osamotnienie, odosobnienie. W poszukiwaniu wartości samotności, [w:] Zrozumieć samotność. Studium interdyscyplinarne, red. P. Domaracki, W. Tyburski, Toruń 2006.

${ }^{13}$ Tamże.

${ }^{14}$ Tamże. 
dzeni, spędzający wiele lat w całkowitym osamotnieniu i poczuciu bezsensowności własnego istnienia, często w warunkach najbardziej „namacalnej” instytucjonalnej izolacji.

\section{O potrzebie kontaktu emocjonalnego i stygmatyzacji osadzonych oraz znaczeniu wsparcia społecznego w procesie readaptacji byłych skazanych}

Więzi uczuciowe mogą być wyrażane na wiele sposobów, niekoniecznie w najbardziej intymny sposób, to jest za pomocą stosunku płciowego. Czuły dotyk, dobre słowo, przytulenie, wcale nie kończące się spółkowaniem, może nadawać i często nadaje naszemu życiu zupełnie inny wymiar - eliminuje uczucie osamotnienia i społecznej izolacji. Już sama świadomość posiadania bliskiej, życzliwej i niosącej emocjonalne wsparcie osoby wydaje się nie do przecenienia ${ }^{15}$. Takiej świadomości, w sposób szczególny, potrzebują osoby odbywające karę pozbawienia wolności oraz opuszczające zakłady karne.

Pierwszą i "naturalną" wskutek pozbawienia wolności dolegliwością jest prawie całkowite ograniczenie swobody działania, kontaktów z rodziną, przyjaciółmi i znajomymi oraz naruszenie więzi z dotychczasowym środowiskiem $^{16}$. Jednak sam fakt osiągnięcia przez kogoś statusu osadzonego nie powinien pozbawiać go możliwości korzystania z przysługującego każdemu prawa do realizowania potrzeby bliskości poprzez kontaktowanie się z rodziną, nawet w najbardziej restrykcyjnych warunkach więziennej izolacji.

Pozbawienie wolności zdecydowanie utrudnia i ogranicza utrzymywanie relacji więźnia z najbliższymi, a niejednokrotnie, w efekcie, jest powodem trwałego zerwania rodzinnych więzi, co nie pozostaje bez znaczenia dla powodzenia pełnego powrotu osadzonego na łono społeczeństwa. Waga bezwzględnej konieczności utrzymywania więzi rodzinnych osób pozostających w warunkach izolacji penitencjarnej została zauważona przez Komitet Ministrów Rady Europy i zaowocowała przyjęciem Europejskich Reguł Więziennych, które regulują kontakty osadzonych ze światem zewnętrznym. Jedne z najważniejszych dotyczących tej kwestii przepisów ERW wskazują, że $\mathrm{e}^{17}$ : „Więźniowie mają prawo porozumiewania się, tak często jak jest to możliwe, poprzez pocztę, telefon lub inne formy komunikacji z ich rodzinami oraz z innymi osobami oraz przedstawicielami organizacji zewnętrznych oraz

\footnotetext{
${ }^{15}$ K. Imieliński, Człowiek $i$ seks, Warszawa 1985.

${ }^{16}$ M. Ciosek, Izolacja więzienna: wybrane aspekty izolacji więziennej w percepcji więźniów i personelu, Gdańsk 1993.

${ }^{17}$ P. Tarwacki, Kontakty skazanego z rodzina - polskie regulacje a Europejskie Reguty Więzienne z 2006 r., Warszawa 2013, 80.
} 
bycie odwiedzanymi przez te osoby"18. Co więcej, "Sposób wizyt pozwala więźniom na utrzymanie i rozwijanie więzi rodzinnych w normalny sposób, tak jak tylko jest to możliwe"19. Należy tu zaznaczyć, że prawo do kontaktu z rodziną opiera się na prawach człowieka i zgodnie z ERW nikt, nawet osoba uznana za niebezpieczną, nie może być prawa tego pozbawiona. W szczególności zaś zwraca się uwagę na fakt, iż „posiadanie przez skazanego rodziny lub innej osoby bliskiej lub godnej zaufania oraz istnienie pomiędzy skazanym a tymi osobami więzi emocjonalnej udokumentowanej i potwierdzonej przez stałe i serdeczne kontakty wzajemne, ma nieoceniony wpływ na efektywność oddziaływań resocjalizacyjnych" ${ }^{20}$. Administracje wszystkich typów i rodzajów zakładów penitencjarnych powinny zatem inspirować osadzonych do jak najczęstszych kontaktów z najbliższymi i zapewnić im godne, i w miarę możliwości normalne ku temu warunki ${ }^{21}$. Już w latach 70. ubiegłego wieku zauważono, że w zakładach karnych, będących najostrzejszą i najbardziej skrajną postacią izolacji pejoratywnej, potrzeby miłości i aktywności seksualnej zbyt często ulegały stałej deprywacji ${ }^{22}$. W dalszej części moich rozważań podejmę próbę wykazania, że i współcześnie, w najwyższym stopniu, w sposób absolutnie bezwzględny i bolesny więzienie „uderza” w potrzebę kontaktu emocjonalnego skazanych.

Liczba i sposób odbywania widzeń skazanych z osobami bliskimi są uzależnione od dyrekcji miejsca osadzenia i typu instytucji. Zakłady typu półotwartego uprawniają skazanych do trzech godzinnych widzeń w miesiącu, podczas których rozmowy osadzonych podlegają stałej kontroli. Osoby odbywające karę pozbawienia wolności w zakładach typu zamkniętego mają prawo do dwóch widzeń w miesiącu, przy czym skazanym „niebezpiecznym” odmawia się prawa do bezpośredniego kontaktu z najbliższymi, a ich widzenia odbywają się pod wzmożonym dozorem w miejscach specjalnie do tego typu widzeń wyznaczonych. Zatem, prawa dotyczące możliwości kontaktowania się osadzonych z bliskimi, które de facto gwarantują im Europejskie Reguły Więzienne, są mocno ograniczone, a niejednokrotnie zupełnie nieuzasadnione, czego przykładem może być autentyczna historia więźnia osadzonego w zakładzie typu zamkniętego, któremu bez powodu systematycznie odmawiano możliwości przytulenia kilkuletniej córki ${ }^{23}$.

\footnotetext{
${ }^{18}$ Rekomendacja Rec (2006) 2 Komitetu Ministrów do państw członkowskich Rady Europy w sprawie Europejskich Reguł Więziennych, przyjęta przez Komitet Ministrów 11 stycznia 2006 r. na 952 posiedzeniu delegatów, prawo nr 24.1, s. 6.

19 Tamże, prawo nr 24.4, s. 6.

${ }^{20}$ P. Tarwacki, Kontakty skazanego z rodzina, s. 79-80.

21 Tamże.

22 B. Waligóra, Funkcjonowanie człowieka.

${ }^{23}$ P. Tarwacki, Kontakty skazanego z rodzina.
} 
Ważną kwestią jest także brak udzielania pozwoleń na widzenia intymne wynikający z indywidualnych przekonań dyrektorów placówek penitencjarnych i społecznych postaw wobec seksualności osób pozbawionych wolności, zwłaszcza w mniejszych miejscowościach. Zdarza się, że mimo iż zakład karny ma możliwość wygospodarowania miejsca na pomieszczenie do wizyt bezdozorowych, to nie zezwala się na nie dla zasady. Polskie społeczeństwo wciąż jest przeświadczone o tym, że więzienie nie jest miejscem, w którym za pieniądze podatników należy umożliwiać „wykolejeńcom” rozładowywanie seksualnego napięcia. Według większości więzienie jest po prostu więzieniem, a kara za złamanie prawa ma być surowa i bolesna. Stąd powszechna opinia, że jakakolwiek dyskusja na temat udzielania osadzonym zezwoleń na widzenia intymne jest bezzasadna, a prawo do tych widzeń nierzadko pozostaje jedynie martwym i niestosowanym przepisem. Tymczasem, możliwość zaspokojenia przez więźniów potrzeby seksualnej i kontaktu emocjonalnego nie tylko minimalizuje ich poczucie osamotnienia, powoduje, że stają się oni znacznie bardziej wyciszeni i chętni do współpracy (co potwierdzają funkcjonariusze Służby Więziennej), ale zmniejsza również stopień ich agresywności, co ma dość duże znaczenie w relacjach ze współosadzonymi. Poza tym, możliwość „normalnego” rozładowania napięcia seksualnego ${ }^{24}$, zarówno samych osadzonych, jak i ich partnerów, ma znamienny wpływ na jakość ich związków, a niejednokrotnie zwiększa szanse na ich przetrwanie.

Bez wątpienia, osoby odbywające karę pozbawienia wolności stanowią grupę najsilniej narażoną na społeczne odrzucenie i stygmatyzację. Już $\mathrm{w}$ trakcie samego odbywania kary wielokrotnie doświadczają napiętnowania mianem przestępcy, kryminalisty, czy bandyty. Często „naznaczona” zostaje również rodzina osadzonego. Nie powinno zatem dziwić, że znaczna część rodzin więźniów zrywa z nimi wszelkie kontakty, zanim ci zdążą odbyć karę do końca. Trudno sobie wyobrazić, z jaką ilością problemów musi zmierzyć się były skazany chcąc ponownie, w zgodzie z obowiązującymi normami, funkcjonować w często nowej dla niego, pozawięziennej rzeczywistości. Wyuczona bezradność, uzależnienia, brak pracy, perspektyw i wsparcia rodziny to tylko część przeszkód, którym nierzadko zupełnie sam musi stawić czoła. Bez otrzymania odpowiedniego wsparcia ze strony społeczeństwa, jego szanse są raczej nikłe. Znaczna część recydywistów przyznaje, że sama chęć zmiany byłego osadzonego nie doprowadzi go do pozytywnej readaptacji społecznej ${ }^{25}$. Najważniejsze są bowiem ludzkie postawy, umiejętność poda-

\footnotetext{
${ }^{24}$ A. Pilarska-Jakubczak, W więzieniu całkiem bez mitości? Forum Penitencjarne, 2012, 4(167).

${ }^{25}$ Ł. Mrózek, Zjawisko wykluczenia społecznego więźniów i osób opuszczających ośrodki penitencjarne. Analiza problemu i możliwości przeciwdziałania zjawisku, Studia Socialia Cracoviensia, 2014, 6, 2(11).
} 
rowania człowiekowi drugiej szansy, a także świadomość, że stygmatyzacja byłych osadzonych jest jednym z najistotniejszych czynników obniżających efektywność społecznej reintegracji ${ }^{26}$. Warto o tym pamiętać, zanim (przekonani o własnej nieomylności) zupełnie bezrefleksyjnie i zbyt pochopnie „wytatuujemy” komuś na ciele "piętno”, skazując go tym samym na piekło osamotnienia.

\section{Od stereotypów do wykluczenia społecznego osób z niepełnosprawnością intelektualną}

„Niepełnosprawność intelektualna” jest pojęciem, które w pedagogice specjalnej pojawiło się stosunkowo niedawno, zastępując stygmatyzujące i pejoratywnie brzmiące pojęcia „upośledzenia” czy „niedorozwoju umysłowego", powodujące szerzenie się niezliczonej ilości mitów. Osoby z niepełnosprawnością intelektualną przez lata postrzegane były niemal wyłącznie przez pryzmat swoich „braków” i „ograniczen", co w świadomości „normalnej” części społeczeństwa czyniło je jednostkami pozbawionymi potencjału rozwojowego, indywidualnych cech osobowości, a nade wszystko istotami odznaczającymi się brakiem typowych dla osób pełnosprawnych intelektualnie przeżyć, odczuć i fundamentalnych potrzeb ${ }^{27}$. To właśnie postawy społeczne, negatywne oddziaływania środowiskowe i błędne przekonania na temat niepełnosprawności intelektualnej są uznawane za główne przyczyny trudności i niepowodzeń w funkcjonowaniu seksualnym osób nią dotkniętych oraz budowaniu przez nie bliskich relacji i intymnych związków ${ }^{28}$. Absolutne przekonanie wielu osób pełnosprawnych o słuszności identyfikowania niepełnosprawności intelektualnej z seksualną przestępczością, nadpobudliwością, nienaturalnymi i nieprawidłowymi potrzebami oraz zachowaniami, dewiacjami i całkowitą aseksualnością, a także niezdolnością do przeżywania i wyrażania miłości ${ }^{29}$, powoduje, że osoby z niepełnosprawnością intelektualną mają wciąż znacznie mniejsze szanse na wolne od samotności, pełnowartościowe, szczęśliwe i aktywne, choć wymagające pomocy i wsparcia, życie.

\footnotetext{
${ }^{26}$ A. Kieszkowska, Inkluzyjno-katalaktyczny model reintegracji społecznej skazanych. Konteksty resocjalizacyjne, Kraków 2012.

${ }^{27}$ Zarząd Główny Polskiego Stowarzyszenia na Rzecz Osób z Upośledzeniem Umysłowym, Niepetnosprawność intelektualna, nowe podejście, Społeczeństwo dla Wszystkich, 1998, 1.

${ }^{28}$ Z. Lew-Starowicz, A. Długołęcka, Edukacja seksualna, Warszawa 2006.

${ }^{29}$ R.J. Kijak, Seksualność osób z niepetnosprawnościa intelektualna, [w:] Dorośli z niepetnosprawnościa intelektualna w labiryntach codzienności. Analiza badań - krytyka podejść - propozycje rozwia$z a n$, red. B. Cytowska, Torun 2011.
} 
Tymczasem, mimo że osobom z niepełnosprawnością intelektualną stale ogranicza się możliwość doświadczania miłości w związkach partnerskich i często izoluje, to ich niezwykłe pragnienie obdarowywania i bycia obdarowywanym uczuciem jest bezsprzeczne. Wiele przypadków potwierdza, że osoby te są całkowicie zdolne do nawiązywania poprawnych relacji i tworzenia szczęśliwych oraz trwałych, opartych na partnerstwie, związków. Należy także podkreślić, że pozostawanie przez osoby niepełnosprawne intelektualnie w bliskim związku nie tylko eliminuje uczucie osamotnienia oraz izolacji, ale często ma dla nich także znaczenie i charakter terapeutyczny. Realizowana w intymnym związku miłość jest również czynnikiem powodującym, że czują się one pełnowartościowe i potrzebne, co niestety zbyt często jeszcze jest negowane przez osoby pełnosprawne ${ }^{30}$.

Wbrew temu co pełnosprawni myślą na temat rozumienia przez niepełnosprawnych seksualności i związanej z nią miłości, przeprowadzone przez Remigiusza Kijaka badania potwierdzają, że w wielu przypadkach osoby z niepełnosprawnością intelektualną potrafią doskonale wyjaśnić, czym jest miłość i jaką rolę odgrywa w ich życiu. W grupie osób niepełnosprawnych intelektualnie, przebadanych przez Kijaka w 2010 roku, jako najwyższą wartość wskazuje się właśnie miłość, co niewątpliwie świadczy o tym, że poszukują one partnerstwa i możliwości realizowania się w bliskich związkach ${ }^{31}$. Okazuje się także, że osoby z niepełnosprawnością intelektualną dokładnie tak samo, jak osoby w pełni sprawne umysłowo, bardzo poważnie myślą o wstąpieniu w związek małżeński, mają też wiele planów związanych z własnym rodzicielstwem. Przebadane przez Aleksandrę Maciarz niepełnosprawne intelektualnie w stopniu lekkim dziewczęta w wieku od 15. do 20. roku życia twierdzą, że realizowanie miłości w małżeństwie jest jednym z ich najistotniejszych życiowych pragnień. Część z nich twierdzi, że była już zakochana, część wciąż pozostaje pod wpływem tego stanu. Zazwyczaj swą miłość chcą realizować z mężczyzną niepełnosprawnym intelektualnie. Uznają, że małżeństwo jest dla nich czymś naturalnym i oczywistym, i marzą, by się w nim spełniać, zarówno jako żona, jak i matka ${ }^{32}$. Badania potwierdzają także chęć posiadania partnerki przez niepełnosprawnych intelektualnie mężczyzn. Wielu z nich chciałoby mieć również swój udział w poczęciu dziecka. Z badań wynika także, że osoby niepełnosprawne inte-

${ }^{30}$ M. Parchomiuk, Seksualność osób z niepetnosprawnościa intelektualna w personalistycznym ujęciu Jeana Vaniera i Antoniego Bartoszka, Społeczeństwo i Rodzina, 2013, 1, 34.

${ }^{31}$ R.J. Kijak, Seksualność osób z niepetnosprawnościa intelektualną.

${ }^{32}$ Z. Janiszewska-Nieścioruk, Respektowanie i egzekwowanie praw seksualnych osób z niepetnosprawnościa - palący, nierozwiąany problem, [w:] Człowiek z niepetnosprawnością w rezerwacie przestrzeni publicznej, red. Z. Gajdzica, Kraków 2013. 
lektualnie, jak ich pełnosprawni rówieśnicy, przy odpowiednim wsparciu ze strony rodziny i instytucji, są w stanie podjąć i wypełniać role rodzicielskie ${ }^{33}$.

\section{O (nie)ludzkich postawach wobec ludzkich potrzeb osób z niepełnosprawnością intelektualną}

Niestety, okazuje się, że w ciągu ostatnich kilkunastu lat jesteśmy świadkami nieustannie zwiększającej się liczby osób dotkniętych niepełnosprawnością intelektualną, które z różnych względów pozbawione są wsparcia i możliwości życia wśród najbliższych, w rodzinie. Zazwyczaj osoby te, najczęściej wbrew własnej woli, oddawane są pod opiekę instytucji, których zadaniem jest pomoc w przezwyciężaniu trudnych życiowych sytuacji uniemożliwiających ich rodzinom zapewnienie im właściwej uwagi i troski. Jednakże część rodzin, mimo iż posiada odpowiednie środki oraz możliwość zorganizowania opieki osobie z niepełnosprawnością intelektualną w środowisku rodzinnym, kierując się wyłącznie własnym egoizmem, decyduje się na umieszczenie osoby niepełnosprawnej w instytucji o charakterze izolacyjnym, skazując ją tym samym na długotrwałe, a niekiedy nawet dożywotnie osamotnienie ${ }^{34}$. Niepokojący jest również fakt (potwierdzony wynikami kontroli w różnych instytucjach pomocy społecznej), że jakość i sposób sprawowania opieki nad mieszkańcami instytucji, które z założenia powinny zajmować się niesieniem pomocy oraz godnym i profesjonalnym zaopiekowaniem się osobami z niepełnosprawnością intelektualną, pozostawiają wiele do życzenia ${ }^{35}$.

Z przeprowadzonych przez Elżbietę Tarkowską i współpracowników badań wynika, że większość finansów wszystkich instytucji pomocy społecznej, ich energia i wysiłek skupiają się na zaspokojeniu biologicznych i fizjologicznych potrzeb, natomiast potrzeby podmiotowości, godności i emocjonalne traktuje się jako mniej ważne i systematycznie pomija. Najbardziej ignorowaną i niemal całkowicie stabuizowaną potrzebą mieszkańców jest potrzeba wyrażania przez nich własnej seksualności oraz tworzenia bliskich, intymnych związków ${ }^{36}$.

Dość powszechną praktyką w domach pomocy społecznej dla osób z niepełnosprawnością intelektualną jest uniemożliwianie mieszkańcom dokonywania swobodnych wyborów w zakresie nawiązywania więzi opartych na

${ }^{33}$ R. Kijak, Seksualność człowieka z niepetnosprawnością intelektualną a rodzina, Warszawa 2014.

${ }^{34}$ B. Witkowska, Osobowościowe uwarunkowania postaw pracowników domów pomocy społecznej wobec osób z zaburzeniami psychicznymi, Lublin 2005.

${ }^{35}$ Ł. Jurek, Wizerunek domów pomocy społecznej w Polsce, Nauki o Zarządzaniu, 2012, 2(11).

${ }^{36}$ J. Niedbalski, Między kontrolą a autonomia - instytucjonalne uwarunkowania życia niepetnosprawnych intelektualnie mieszkańców domów pomocy społecznej, Niepełnosprawność - Zagadnienia, Problemy, Rozwiązania, 2013, 4. 
uczuciach oraz nieograniczonego kontaktowania się z innymi mieszkańcami. Oznacza to w praktyce brak możliwości zaspokojenia przez nich potrzeby kontaktów emocjonalnych i bliskości. Kontrolowanie wzajemnych relacji pomiędzy mieszkańcami już na poziomie przyjaźni poprzez systematyczne ich ograniczanie, rozdzielanie i umieszczanie na różnych piętrach domu, tłumaczone jest przez sam personel, jako działanie dla ich "dobra”. W rzeczywistości jednak działania takie służą utrudnianiu mieszkańcom tworzenia intymnych, a z punktu widzenia pracowników DPS-ów niewygodnych, niepożądanych i niebezpiecznych związków ${ }^{37}$.

Agnieszka Kumaniecka-Wiśniewska badająca rzeczywistość i funkcjonowanie mieszkańców placówek opieki instytucjonalnej, wielokrotnie podkreślała, że w większości placówek personel nie kryjąc negatywnych postaw wobec seksualności swoich podopiecznych, systematycznie pozbawia ich wszelkich jej atrybutów. Przeważnie każda próba podjęcia jakiejkolwiek aktywności seksualnej przez mieszkańców wiązała się z natychmiastową eliminacją niepożądanych przez personel zachowań, poprzez ostrą krytykę, kary fizyczne bądź wyciszanie medykamentami. Mimo iż większość domów pomocy społecznej jest placówkami świeckimi, to najczęściej opiekunowie i dyrekcja tłumaczą eliminację zachowań seksualnych rozterkami natury religijnej i otwarcie przyznają, że nigdy nie pozwolą na pozamałżeńskie kontakty seksualne, co jest jednoznaczne $\mathrm{z}$ deprywacją podstawowej potrzeby każdego człowieka, jaką jest potrzeba kontaktu emocjonalnego i bliskości ${ }^{38}$. $\mathrm{W}$ tej sytuacji nie powinny dziwić znajdowane w literaturze przedmiotu cytowane niechlubne opinie na temat domów opieki i pełne żalu wypowiedzi pensjonariuszy, którzy otwarcie sprzeciwiają się systematycznej deprywacji ich najważniejszych potrzeb, twierdząc, że: Przeklinamy nasze życie i naszych najbliższych, którzy oddając nas do przytutku - żywcem nas pogrzebali ${ }^{39}$.

Warto w tym miejscu zaznaczyć, że nowy nurt życia seksualnego jednoznacznie precyzuje zadania dotyczące sfery seksualnej, wskazując na konieczność przeciwdziałania izolacji, segregacji i dyskryminacji w zakresie seksualności bez względu na płeć, niepełnosprawność, czy stan zdrowia. Praktycy i teoretycy nieustannie analizujący życie seksualne, partnerstwo oraz rodzicielstwo osób z niepełnosprawnością intelektualną przebywających $\mathrm{w}$ domach pomocy społecznej postulują o uznanie potrzeb seksualnych tych osób i ich prawa do miłości, tworzenia związków oraz czerpania z nich radości i satysfakcji ${ }^{40}$.

${ }^{37}$ Tamże.

${ }^{38}$ A. Załustowicz, Osoby z zaburzeniami psychicznymi mieszkające w domu pomocy społecznej niektóre właściwości rozwoju i funkcjonowania seksualnego, Nowiny Lekarskie, 2011, 80, 5.

${ }^{39} \mathrm{~T}$. Zbyrad, Instytucje opieki totalnej, s. 61.

${ }^{40}$ A. Załustowicz, Osoby z zaburzeniami. 


\section{W stronę zmian: czyli o tolerancji i rozumieniu potrzeb osób izolowanych}

Jeszcze do niedawna problemy seksualności oraz zaspokajania potrzeb bliskości i miłości osób z niepełnosprawnością intelektualną były w literaturze mocno ignorowane ${ }^{41}$, natomiast pragnienia oraz tęsknoty osób odbywających karę pozbawienia wolności mało kogo przejmowały. Współcześnie jednak w wielu publikacjach temat ten jest coraz częściej dyskutowany i analizowany, a zmowa milczenia została przez wiele autorytetów przełamana. I choć w oczach zwykłych ludzi wszelkie przejawy seksualności i zachowania służące zaspokojeniu potrzeby bliskości osadzonych i osób z niepełnosprawnością intelektualną są systematycznie potępiane, nierzadko traktowane jako graniczące z patologią, a już na pewno postrzegane jako niewłaściwe, to cieszy fakt, że w świecie nauki seksualna sfera życia osób izolowanych społecznie została „dostrzeżona” i uznana za wartą poświęcenia jej uwagi.

Optymizmem napawają również wyniki poczynionych przeze mnie badań ${ }^{42}$ nad seksualnością osób izolowanych (zwłaszcza zaś części poświęconej zbadaniu postaw personelu instytucji wobec seksualności osób izolowanych), których celem było ukazanie subiektywnego sposobu rozumienia i przeżywania własnej seksualności oraz funkcjonowania i potrzeb seksualnych osób poddanych instytucjonalnej izolacji, a także zbadanie i opisanie zależności pomiędzy możliwością wyrażania seksualności przez osoby poddane izolacji a wspomnianymi już postawami personelu. W badaniach podjęto próbę odpowiedzenia na pytanie: jak badane osoby ukazują realną możliwość wyrażania przez nie własnej seksualności w warunkach instytucjonalnej izolacji? W celu dokładnego poznania przedmiotu badań zastosowano jakościową orientację badawczą i metodę studium przypadku. Do gromadzenia materiału empirycznego wykorzystano technikę wywiadu narracyjnego i posłużono się narzędziem badawczym $\mathrm{w}$ postaci dyspozycji do wywiadu. W skład próby badawczej weszło 8 osób wytypowanych przez przydzielonych mi przez dyrektorów instytucji opiekunów. Wśród nich znajdowały się: 3 osoby osadzone odbywające karę pozbawienia wolności w wymiarze: 32 miesięcy, 7 lat i 25 lat oraz 5 osób z niepełnosprawnością intelektualną w stopniu umiarkowanym i znacznym. Ponadto, każdy z wyznaczonych opiekunów wyraził zgodę na udzielenie wywiadu jako przedstawiciel personelu instytucji, na terenie których przeprowadzono badania. Byli to: wychowawca badanych osadzonych oraz terapeutka i opiekunka respondentów z niepełnosprawnością intelektualną. Treść wywiadów (po wcześniejszym uzyskaniu zgody zarów-

\footnotetext{
${ }^{41}$ R.J. Kijak, Seksualność osób z niepetnosprawnościa intelektualną.

${ }^{42}$ Badania przeprowadzono w maju 2016 roku, w ramach pracy magisterskiej: Seksualność osób izolowanych - pomiędzy teoria a realną szansa wyrażania.
} 
no dyrekcji, jak również respondentów) została zarejestrowana na dyktafonie. Efektem końcowym badań było ukazanie sposobu funkcjonowania w sferze seksualności osób z niepełnosprawnością intelektualną i osadzonych, ze szczególnym uwzględnieniem możliwości i trudności w wyrażaniu przez nie własnej seksualności w instytucjach o charakterze izolacyjnym (tj. koedukacyjnym domu pomocy społecznej i zakładzie karnym typu półotwartego), znajdujących się na terenie województwa lubuskiego (dyrektorzy instytucji nie wyrazili zgody na podanie dokładnej lokalizacji zarządzanych przez nich placówek), a także opisanie postaw personelu instytucji wobec seksualności osób poddawanych instytucjonalnej izolacji.

Okazuje się, że prezentowane postawy zbadanego przeze mnie personelu instytucji wobec seksualności oraz potrzeb bliskości i miłości ich podopiecznych zasadniczo odbiegają od tych, które tak często jeszcze opisywane są w literaturze przedmiotu.

Postawy personelu odwiedzonego przeze mnie domu pomocy społecznej dla osób z niepełnosprawnością intelektualną charakteryzują się bardzo dużą tolerancją i zrozumieniem. Można było odnieść wrażenie, że pracownicy są ludźmi o ogromnych pokładach empatii, darzącymi swoich podopiecznych sympatią i szacunkiem. Opiekunowie wiedzą, jak duże znaczenie ma dla mieszkańców domu możliwość posiadania bliskiej osoby, doskonale znają swoich podopiecznych i ich potrzeby, a co ważne - do każdego podchodzą indywidualnie. Szanują ich seksualną naturę i przykładają wszelkich starań, aby zapewnić im godne warunki oraz intymność w sytuacjach, które tego wymagają (także w sytuacji, kiedy przypadkiem staną się świadkami współżycia seksualnego mieszkańców). Wiedzą, z czym wiąże się udaremnianie potrzeby seksualnej. Dbają także o uświadamianie mieszkańców i odpowiedni dobór środków antykoncepcyjnych. Służą im wsparciem, są otwarci i zawsze chętnie pomagają $\mathrm{w}$ rozwiązywaniu ich problemów. Można powiedzieć, że są pracownikami niezwykle kompetentnymi - doskonale orientują się $\mathrm{w}$ temacie seksualności osób z niepełnosprawnością intelektualną. Znają niedomagania systemu opieki i wiedzą, na jakie trudności mogą napotkać ich podopieczni w przypadku pojawienia się niepożądanej ciąży - niepożądanej w sensie takim, że będzie ona wynikiem współżycia osób, które ich zdaniem samodzielnie nie potrafiłyby podołać rodzicielstwu. Co najistotniejsze, mimo pewnych wątpliwości, nie odbierają im całkowicie prawa do bycia rodzicami i popierają zawiązywanie przez nich związków partnerskich. Wiedzą także, jak niezwykle ważna jest kwestia seksualnego edukowania rodziców i dzieci z niepełnosprawnością intelektualną. Starają się zapewnić mieszkańcom wszystko, czego ci potrzebują - oczywiście zgodnie z tym, jakimi środkami dysponują. I wreszcie, mając świadomość, że w ich domu pomocy społecznej nie jest możliwe zaopiekowanie się rodzinami, czy matkami samotnie wy- 
chowującymi swoje dzieci, skłaniają się ku tworzeniu mieszkań chronionych, które umożliwiłyby im w miarę autonomiczne życie w społeczeństwie. Personel podejmuje zatem wszelkie możliwe kroki w celu przeciwdziałania poczuciu osamotnienia ich podopiecznych i traktuje ich z prawdziwą godnością. Co więcej, potwierdzają to sami mieszkańcy domu pomocy społecznej.

Jeśli chodzi o takie potrzeby osadzonych, jak: potrzeba akceptacji, intymności, godnego traktowania, samodecydowania, bliskości i miłości, można powiedzieć, że narracje biorących udział $w$ badaniu skazanych jednoznacznie wskazują, iż w warunkach izolacji penitencjarnej, faktycznie, w większym lub mniejszym stopniu, deprywacji ulegają wszystkie wymienione powyżej potrzeby. W szczególności zaś wskazali na potrzebę intymności, godnego traktowania, wolnej woli, bliskości i miłości. Według więźniów ich potrzeby nie interesują nikogo, włącznie z wychowawcami.

W ocenie osób odbywających karę pozbawienia wolności, szansa na pełne wyrażanie przez nie własnej seksualności w warunkach izolacji penitencjarnej została określona jako: żadna, znikoma i bardzo mała. Jednak, po przeprowadzeniu analizy wypowiedzi zarówno osadzonych, jak i przedstawiciela Służby Więziennej (w tym przypadku wychowawcy badanych osadzonych), chcąc zająć obiektywne stanowisko, zupełnie nie można zgodzić się z pierwszą opinią. Mimo iż bez cienia wątpliwości wszystkie związane z ludzką seksualnością potrzeby w warunkach więziennej izolacji ulegają znacznej deprywacji, to jednak osadzeni mają pewne nikłe szanse na zaspokojenie potrzeby bliskości i miłości, chociażby w listach, podczas rozmów telefonicznych, czy w trakcie widzeń. Gdyby funkcjonariuszom faktycznie zależało, aby utrudnić skazanym seksualną ekspresję i zaspokojenie ich fundamentalnych potrzeb, wówczas bez wątpienia osoby odbywające karę pozbawienia wolności odczułyby to boleśnie.

Tymczasem, mimo iż wypowiedź wychowawcy wskazuje, że postawy przedstawicieli Służby Więziennej tego konkretnego zakładu karnego charakteryzują się dużą nieufnością i podejrzliwością wobec osadzonych, to jednak zainteresowanie potrzebami skazanych i świadomość istnienia tych potrzeb jest tu niewątpliwa. Wychowawca doskonale zdaje sobie sprawę z korzyści, jakie niesie za sobą ciągły i bliski kontakt osadzonych z rodzinami, świetnie orientuje się także, jakie mogą być konsekwencje zerwania tych relacji. Dlatego, tak często, jak to możliwe, nagradza swoich podopiecznych dodatkowymi widzeniami. Mimo iż nie jest do końca przekonany o słuszności umożliwiania osadzonym korzystania z widzeń intymnych, można było odnieść wrażenie, że gdyby decyzja o udzielaniu skazanym nagród w tej formie należała do niego, przychyliłby się do niej. Nagrody w tejże postaci jednak nie są tu udzielane. Podczas widzeń wychowawca często obserwuje przejawy potrzeby bliskości i miłości osadzonych i choć musi dostosowywać się do obowią- 
zujących regulaminów, zdarza się, że on i część pozostałych funkcjonariuszy Służby Więziennej "przymyka oczy” na pewne, „zbyt wylewne” zachowania zarówno skazanych, jak i odwiedzających ich bliskich. Niektórzy pracownicy SW powstrzymują się także od konfiskowania osadzonym zabronionych regulaminem czasopism o charakterze erotycznym. Można zatem przypuszczać, że poniekąd rozumieją konieczność zaspokajania przez skazanych potrzeby utrzymywania więzi z najbliższymi i seksualnej ekspresji.

Znając także sytuację osadzonych po opuszczeniu przez nich zakładu karnego, mój rozmówca sugeruje konieczność większego otwarcia się społeczeństwa na byłych skazanych oraz umożliwienie im podejmowania godnie płatnej pracy, bo jak twierdzi, póki co: osadzeni sa traktowani przez społeczeństwo, jak trędowaci. I choć nierzadko, wykonując pracę w ramach wolontariatu, postrzegani są jako doskonali pracownicy, są pożądani i lubiani, to w sytuacji, kiedy tę samą pracę wykonują odpłatnie, traktowani sa, jak robole, jak maszyny do zarabiania pieniędzy $i$ do ciężkiej pracy.

Zaprezentowany tu jedynie wycinek wyników badań przeprowadzonych w skrajnie różnych warunkach instytucjonalnej izolacji pozwala przypuszczać, że potrzeby bliskości i tworzenia głębokich relacji osób izolowanych społecznie zostały zauważone nie tylko przez naukowe autorytety, ale również profesjonalny personel instytucji o charakterze izolacyjnym. W głównej mierze od jego postaw wobec seksualności i potrzeb osób izolowanych społecznie uzależnione jest, na ile osoby poddawane izolacji będą mogły spełniać się $w$ tej najbardziej z intymnych i fundamentalnych sfer swojego życia. Natomiast od samych osób izolowanych zależy, w jakim stopniu wykorzystają dane im przez personel szanse.

\section{Podsumowanie i wnioski}

Nie ma wątpliwości, że każdy człowiek, niezależnie czy jest sprawny, czy niepełnosprawny, czy żyje w zgodzie z prawem, czy wbrew niemu, jest istotą ludzką silnie odczuwającą potrzebę bliskości i miłości. Ma zatem niezbywalne prawo do wyrażania siebie, życia w poczuciu bycia potrzebnym, akceptowanym i traktowanym z należną mu godnością. Niestety, w literaturze przedmiotu wciąż jeszcze można odnaleźć liczne przykłady, że nasze społeczeństwo nie jest gotowe, aby w pełni fakt ten zaakceptować. Dlatego, poza bezsprzeczną koniecznością udzielania osobom izolowanym społecznie odpowiedniej pomocy i szeroko rozumianego wsparcia oraz dawania im możliwości większego decydowania o sobie, co niewątpliwie wiąże się z absolutną potrzebą wprowadzania zmian w systemie opieki i resocjalizacji, tak istotne wydaje się objęcie wszystkich ludzi właściwą edukacją, pozwalającą 
wyrwać ich ze stereotypowego myślenia i uprzedzeń, a także uświadomić im konsekwencje uniemożliwiania człowiekowi pełnego doświadczania bliskości drugiej osoby. Mówiąc o konieczności edukowania, należy wziąć pod uwagę nie tylko osoby, które problem ten w bezpośredni sposób dotyka, to jest same osoby izolowane, ich rodziny i personel, ale całe społeczeństwa, których otwarcie się na osoby niepełnosprawne, osadzonych i osoby opuszczające zakłady karne, w dużym stopniu może zwiększyć ich szanse na pełniejsze realizowanie się i wyzwolić ich z poczucia osamotnienia.

Niniejszy artykuł miał na celu nie tylko ukazać konsekwencje społecznej izolacji, ale również uświadomić czytelnikowi, że sposób w jaki postrzegamy innych oraz jak my jesteśmy przez nich postrzegani ma doniosłe znaczenie w tworzeniu poprawnych więzi międzyludzkich. W czasach, kiedy nasze życie ulega coraz szerszej instytucjonalizacji, a człowiek zamyka się na drugiego człowieka i jego potrzeby, powodując, że pochłania go coraz większa samotność - miłość, ta zwykła miłość do drugiego człowieka, odgrywa doniosłe znaczenie $^{43}$ - jest jedynym sposobem na wydostanie się z „klatki osamotnienia”. Człowiek bowiem jest istotą, która do pełni szczęścia potrzebuje drugiego człowieka, ludzi, którzy wzbogacą i upiększą jego osobowość, obdarzą go uczuciem, spowodują, że będzie czuł się potrzebny, ceniony i akceptowany jako w istocie niepowtarzalna i z całą pewnością nie stworzona do życia poza marginesem społecznym psychofizyczna jedność.

\section{BIBLIOGRAFIA}

Adamczyk M., Choroba i jej indywidualna koncepcja, [w:] Elementy psychologii klinicznej, red. B Waligóra, Wydawnictwo Naukowe UAM, Poznań 1985.

Ciosek M., Izolacja więzienna: wybrane aspekty izolacji więziennej w percepcji więźniów i personelu, Wydawnictwo Uniwersytetu Gdańskiego, Gdańsk 1993.

Goffman E., Piętno. Rozważania o zranionej tożsamości, Gdańskie Wydawnictwo Psychologiczne, Gdańsk 2005.

Gołaszewska M., Imiona miłości. Nowożytna myśl o życiu erotycznym, Towarzystwo Autorów i Wydawców Prac Naukowych „Universitas”, Kraków 1992.

Imieliński K., Człowiek i seks, Instytut Wydawniczy Związków Zawodowych, Warszawa 1985.

Janiszewska-Nieścioruk Z., Respektowanie i egzekwowanie praw seksualnych osób z niepetnosprawnościa - palacy, nierozwiązany problem, [w:] Człowiek z niepetnosprawnościa w rezerwacie przestrzeni publicznej, red. Gajdzica Z., Oficyna Wydawnicza Impuls, Kraków 2013.

Jurek Ł., Wizerunek domów pomocy społecznej w Polsce, Nauki o Zarządzaniu, 2012, 2(11).

Kieszkowska A., Inkluzyjno-katalaktyczny model reintegracji społecznej skazanych. Konteksty resocjalizacyjne, Oficyna Wydawnicza Impuls, Kraków 2012.

${ }^{43}$ M. Gołaszewska, Imiona miłości. Nowożytna myśl o życiu erotycznym, Kraków 1992. 
Kijak R.J., Seksualność osób z niepetnosprawnościa intelektualna, [w:] Dorośli z niepetnosprawnościa intelektualna w labiryntach codzienności. Analiza badań - krytyka podejść - propozycje rozwiazań, red. B. Cytowska, Wydawnictwo Adam Marszałek, Torun 2011.

Kijak R., Seksualność człowieka z niepetnosprawnościa intelektualna a rodzina, Wydawnictwo Lekarskie PZWL, Warszawa 2014.

Lew-Starowicz Z., Długołęcka A., Edukacja seksualna, Świat Książki, Warszawa 2006.

Mrózek Ł., Zjawisko wykluczenia społecznego więźniów i osób opuszczających ośrodki penitencjarne. Analiza problemu i możliwości przeciwdziałania zjawisku, Studia Socialia Cracoviensia, 2014, 6, 2(11).

Niedbalski J., Między kontrola a autonomia - instytucjonalne uwarunkowania życia niepetnosprawnych intelektualnie mieszkańców domów pomocy społecznej, Niepełnosprawność Zagadnienia, Problemy, Rozwiązania, 2013, 4.

Nomejko A., Dolińska-Zygmunt G., Zdrojewicz Z., Poczucie jakości życia a satysfakcja z życia seksualnego - badania własne, Seksuologia Polska, 2012, 10(2).

Parchomiuk M., Seksualność osób z niepetnosprawnościa intelektualną w personalistycznym ujęciu Jeana Vaniera i Antoniego Bartoszka, Społeczeństwo i Rodzina, 2013, 1, 34.

Pilarska-Jakubczak A., W więzieniu całkiem bez miłości? Forum Penitencjarne, 2012, 4(167).

Sarzała D., Patologiczne zachowania więźniów w kontekście izolacji i resocjalizacji penitencjarnej, Oficyna Wydawnicza ASPRA-JR, Warszawa 2013.

Ślęczek-Czakon D., Samotność, osamotnienie, odosobnienie. W poszukiwaniu wartości samotności, [w:] Zrozumieć samotność. Studium interdyscyplinarne, red. P. Domaracki, W. Tyburski, Wydawnictwo UMK, Toruń 2006.

Tarwacki P., Kontakty skazanego z rodzina - polskie regulacje a Europejskie Reguty Więzienne z 2006 r., Przegląd Więziennictwa Polskiego, Wydawnictwo Centralnego Zarządu Służby Więziennej Ministerstwa Sprawiedliwości, Warszawa 2013.

Waligóra B., Deprywacja potrzeb u osób pozbawionych wolności, [w:] Problemy wspótczesnej penitencjarystyki w Polsce, red. Hołyst B., Wydawnictwo Prawnicze, Warszawa 1984.

Waligóra B., Funkcjonowanie człowieka w warunkach izolacji więziennej, Wydawnictwo Naukowe UAM, Poznań 1974.

Witkowska B., Osobowościowe uwarunkowania postaw pracowników domów pomocy społecznej wobec osób z zaburzeniami psychicznymi, Towarzystwo Naukowe KUL, Lublin 2005.

Załustowicz A., Osoby z zaburzeniami psychicznymi mieszkajace w domu pomocy społecznej niektóre właściwości rozwoju i funkcjonowania seksualnego, Nowiny Lekarskie, 2011, 80, 5.

Zarząd Główny Polskiego Stowarzyszenia na Rzecz Osób z Upośledzeniem Umysłowym, Niepetnosprawność intelektualna, nowe podejście, Społeczeństwo dla Wszystkich, 1998, 1.

Zbyrad T., Instytucje opieki totalnej jako forma zniewolenia i kontroli nad człowiekiem potrzebujacym pomocy - na przykładzie domów pomocy społecznej, Roczniki Nauk Społecznych, 2012, IV(40), 2.

\section{Spis aktów prawnych}

Rekomendacja Rec (2006) 2 Komitetu Ministrów do państw członkowskich Rady Europy w sprawie Europejskich Reguł Więziennych, przyjęta przez Komitet Ministrów 11 stycznia 2006 r. na 952 posiedzeniu delegatów, prawo nr 24.1.

Rekomendacja Rec (2006) 2 Komitetu Ministrów do państw członkowskich Rady Europy w sprawie Europejskich Reguł Więziennych, przyjęta przez Komitet Ministrów 11 stycznia 2006 r. na 952 posiedzeniu delegatów, prawo nr 24.4 . 